\title{
The Ideology of the German Neukirchen Mission and Its Implication on Education in Tana River County, Kenya 1887-1986
}

\author{
Gitonga P. Kimani (Corresponding author) \\ School of Education \\ Educational Foundations Department \\ Box 43844-00100 \\ Nairobi \\ Email: kimanipeter@ku.ac.ke \\ James E. Otiende (Prof.) \\ School of Education \\ Educational Foundations Department \\ Box 43844-00100 \\ Nairobi \\ Email: otiende.james@ku.ac.ke \\ Augustine M. Karugu (Prof.) \\ School of Education \\ Educational Foundations Department \\ Box 43844-00100 \\ Nairobi \\ Email: karugu.augustine@ku.ac.ke
}

Received: July 30, 2020 Accepted: August 22, 2020 Published: September 15, 2020

doi:10.5296/ijld.v10i3.17715 URL: https://doi.org/10.5296/ijld.v10i3.17715 


\section{Abstract}

This paper examines the ideology of the German Neukirchen Mission and its implication on education in Tana River County, Kenya 1887 to 1986 . Western education and Christianity in Africa were introduced by Christian missionaries from Europe as early as the $16^{\text {th }}$ century but took root in around the mid-nineteenth century. In Tana River, several missionary organizations ventured in the area notably the Methodist Missionary Society (MMS), the German Neukirchen Mission (GNM), the Holy Ghost Fathers (HGF) and the Swedish Mission. They all gave up in the area due to a multiplicity of hardships save for the GNM which hang on and continued with evangelization and education. Consequently, there is need to look at the ideology of the GNM that influenced its resolve to persist in an area shunned by its contemporaries. An understanding of GNM's ideology would come in handy in helping to improve education standards in the area bearing in mind that the same problems that bedeviled the region have to a large extent remained to date The study had three objectives which were: to identify the educational institutions opened by the GNM in Tana River County 1887-1986; to establish the hardships experienced by the GNM in Tana River County in the period 1887-1986 and to examine the ideology which influenced GNM's activities in Tana River County in the period 1887-1986. The time frame was 1887 to 1986 . This period covers the time the GNM arrived in Tana River to the year the first secondary school was established at Ngao i.e 1986. Ngao served as GNM's mission base or station since the arrival of the missionaries in the region. The study was historical in nature and utilized a historical research design. Sources of data were both primary and secondary sources. Primary sources were mainly drawn from the Kenya National Archives (KNA) and schools and churches in Tana River. Document analysis was also utilized as a data collection method. The research instruments were interview schedules and Focus Group Discussions (FGDs). Respondents to these research instruments were retired educationists, civil servants and politicians, church leaders and village elders selected through purposive and snowball sampling techniques; all totaling 33. Collected data was analyzed through qualitative and quantitative methods while documents were analyzed through external and internal criticism. The study found out that the GNM established 31 primary schools 28 of which are still operational. The GNM missionaries experienced several challenges among them deportation during the two World Wars, frequent Somali attacks, floods, poor transport network, malaria infections and inadequate finances. The ideology was examined under five perspectives namely The Great Commission, Faith Mission, Reformed Theology, Social Darwinism and Socio-Political and Economic view point. The study recommends improvement of road and school infrastructure, investing more on Technical and Vocational Education and Training (TVET) institutions, opening of a secondary school wing in every primary school, delocalization of teachers and establishment of an institution of higher learning in the area.

Keywords: ideology, implication, perspectives, western education, evangelization

\section{Introduction}

Tana River County, like other parts of Kenya, embraced Christianity and Western education through the missionary work of the Methodist Missionary Society (MMS) and the German 
Neukirchen Mission (GNM). MMS and a few other missionary organizations which equally attempted to serve in the area notably the Catholic Holy Ghost Gathers (HGF) and Swedish Mission were unable to persevere the myriad of hardships and relocated to upcountry Kenya (Nthamburi, 1982; Gissel \& Gissel, 1991), leaving GNM as the only missionary organization in the area.

The pioneer GNM missionary was Reverend Ferdinard Wurtz who arrived in Tana River on $17^{\text {th }}$ March 1887. He was followed by others in later years that included Reverend Anna Weber, August Kraft, Christine Sonnischen, Wilhelm Schmidt, Reverend Becker, Wilhelm May, Captain Steubing, Herman Muller, Fritz Gissel and Hannah Gissel. The GNM introduced Western education in order to be able to spread Christianity. Rev. Wartz worked with pioneer converts to translate sections of the New Testament Bible into Pokomo language.

The GNM missionaries were deported by the British in 1914 following the outbreak of the First World War which saw Germany and British in opposing camps. They returned in 1926 but were again deported in 1939 with the outbreak of the Second World War. They were allowed back in the late 1960s after Kenya attained independence. In 1986, Ngao Secondary School in Tana River was established to fulfill GNM's long cherished dream to establish a secondary school of national status. The brainchild of this dream was German educationist Herman Muller who came to Tana River as a missionary cum teacher in the 1930s. Indeed Ngao Girls Secondary School was given national school status in 2014. The GNM had used Ngao as their base or headquarters in Tana River in all the years they operated in the region.

\subsection{Research Problem}

The GNM remained in an area that was shunned by other missionary organizations and kept returning back even after being deported. By 1914, a total of 17 missionaries seconded to the area had died. They included Heinrich Blecher, Alwine Weber, Regine Bocking, Ferdinard Wurtz, Wilhelm Klotz, Anna Weber, Johanna Heyer, Berta Wartenberg, Friedrich Fink, Elisabeth Bamberger, Elisabeth Heyer, Johannes Blankertz, Paula Warterberg, Klara Weidt, Elesabith Schmidt, Christine Sonnichsen and August Kraft (Gissel \& Gissel, 1991, p.239).

Such resilience by GNM needs further examination to see the ideology that propelled the organization to sustain their work in such a problematic area. Failure to look at the ideology of GNM would leave us uninformed on the driving force behind their endurance and by extension miss out on drawing insights that could help in improving the delivery of critical services (education included) in such regions.

The Sustainable Development Goal 4 (SDG 4) reiterates the need to ensure inclusive and equitable quality education and promote lifelong learning opportunities for all (United Nations SDGs, 2015; GOK, 2016). Arid and Semi-arid Lands (ASALs) have been disadvantaged in education provision since colonial times and a look at the activities of the GNM which promoted education in Tana River County could serve as a guiding principle and motivation to bring at par ASAL areas in terms of educational gains. 


\section{Research Methodoly}

The locale of the study was Tana River County in the former Coast Province, Kenya. Tana River County borders Garissa County to the East, Lamu county and Indian Ocean to the South, Kitui and Meru Counties to the West and Isiolo County to the North. The historical method research design was preferred in this study because it entailed tracing GNM's arrival in the late 1880s to 1986 when Ngao Secondary School was established to accomplish GNM's desire since 1930s to open a secondary school in the caliber of Alliance High school which had been started by an alliance of protestant missions in 1926 (Smith 1973).

Both primary and secondary sources of data were used. Primary sources included documents and written materials obtained at the Kenya National Archives (KNA) in Nairobi and in churches and schools in Tana River County. Secondary sources were books mainly from university libraries. Artifacts or items used by the missionaries that were available also served as source of information. Data collection instruments were Oral Interviews and Focus Group Discussions (FGDs). Gathered documents were also analyzed to augment on the information obtained from the research instruments. Documents and artifacts were obtained in Tana River schools and churches while oral interviews were conducted on retired educationists, civil servants, politicians and church leaders who were directly or indirectly beneficiaries of GNM'S activities in Tana River. Documents and artifacts analyzed included church files, school records, District Education Board (DEB) minutes of meetings, photographs of missionaries, baptismal cards, inscriptions on grave sites of missionaries, sewing machines, stoves, workshop tools, missionaries' diaries, documents written in German language and hymn books and Bibles translated into Pokomo language. A total of 33 respondents were interviewed. FGDs were subjected to 8 village elders of Ngao which was GNM's headquarters or mission station. Most of them by virtue of their age had interacted with the missionaries. Collected data was analyzed both qualitatively and quantitatively. Documents and artifacts were subjected to external and internal criticism to ascertain their authenticity.

\section{Presentation of Findings}

\subsection{Learning Institutions opened by GNM in Tana River County}

The GNM managed to establish 31 primary schools in Tana River county namely Garsen, Wema, Marembo, Kulesa, Hola, Wenje, Ngao, Mwanadhamba, Golbanti, Mudzimkuu, Laini, Mikinduni, Pumwani, Munyuni, Munazini, Maroni, Masalani, Chewani, Oda, Kibusu, Gardeni, Musizuei, Mwina, Muwazini, Kiapani, Belezoni, Chunoni, Baumo, Ovo, Makere and Wanabamba.

The Mission also opened four secondary schools namely Tarasaa, Hola, Wenje and Ngao between 1968 to 1986. GNM also established two technical schools at Belozoni and Hola, one Girls' Special School at Ngao, one Teachers Training College at Ngao and one Village polytechnic in Tarasaa. When Beecher Commission recommended a 4-4-4- education system in 1949 (Beecher Report 1949; Sheffield 1971:13; Sifuna \& Otiende 1994), Hola, Ngao and Wenje were elevated to intermediate schools in the District. 
23 of the primary schools are still operational to date using the same names. Two others changed names; these are Wema to Reuben Mwewe and Ngao to Arap Moi. Three relocated due to floods and changed names; namely Mwanadhamba to Tarasaa, Pumwani to Handa Mpya and Oda to Furaha. Three ceased to exist mainly due to insecurity; they are Mudzimkuu, Musizuei and Wanabamba. Belezoni and Hola technical schools, the Girls' Special School and the Teachers' College declined and eventually closed when the Germans were deported after the outbreak of the Second World War. One respondent, Garisse Israel Gudina lamented that he wished the Germans had remained in Tana River because all indications show that the area could have advanced a lot by now especially in the education sector (23/11/2017).

\subsection{Challenges Faced by GNM}

The German evangelists and educationists faced various hardships and challenges in their work. These included extreme temperatures they had not been used to, mosquitoes and the accompanying malaria disease, frequent attacks by the Somali, inadequate finances and indifferent British colonial officials. The floods of River Tana also posed a challenge because in several occasions they were forced to relocate. They also faced opposition from the traditional witchdoctors who felt their influence was being threatened by the new religion and education. Transport was a big problem due to lack of roads, and they had to rely on boat transport (Neghea $1 \& 11$ ).

Surprisingly, it was evident that nothing much has changed since then and most of the challenges mentioned above continue bedeviling the County. The floods resulting from River Tana bursting its banks still cause havoc in the County. The seven folk dams upstream are unable to contain the river during heavy rains as happened in the first half of 2018.Learning was interrupted in most of the schools. Conflict between the Pokomo and the Orma, the two major ethnic groups in the County is a perennial problem especially during election time. This again affects education negatively. Road network is poor with only one tarmac road from Malindi to Garsen. The issue of accessing the learning institutions and logistics of starting new ones not to mention attracting teachers to the area are all adversely affected by this unfortunate state of affairs.

\subsection{The Ideology of GNM}

The ideology of GNM was looked at in five different perspectives namely The Great Commission, GNM as a Faith Mission, Reformed Theology, Social Darwinism and Socio-Political and Economic factors.

\section{(i) The Great Commission}

In Christianity, The Great Commission is the instruction of the resurrected Jesus Christ to his disciples to spread his teachings to all the nations of the world. Although the command was initially given directly only to Christ's eleven remaining apostles, evangelical Christian theology has typically interpreted the commission as a directive to all Christians of every time and place, particularly because it seems to be a restatement or moving forward of the last part of God's covenant with Abraham in Genesis 12 and 22. God promised Abraham that he would make his descendants as numerous as the stars of the sea and as sand which is on the seashore. 
The Great Commission eventually became a tenet in Christian theology emphasizing ministry, missionary work, evangelism and baptism. The term was first used by Dutch missionary Justian von Welz but was popularized by Hudson Taylor (Castleman, R.F. n.d). Undoubtedly, the Great Command by the founder of Christianity, Jesus Christ motivated missionaries of various Christian denominations to leave their home countries and go and spread Christianity in faraway lands. Jesus had emphasized that he would return for the second time very soon and speculation was rife that this would be at the close of the century or millennium. History shows that such speculations emerge every time a century or millennium is coming to a close. This could partly explain the urgency of missionaries to preach the gospel towards the end of the $19^{\text {th }}$ century. Education was one of the tools the missionaries used to enable them spread the Gospel.

Education comes in handy because GNM and indeed all other missionaries realized that evangelization would be more effective and would spread faster if a big number of the population was literate (Bantock 1980, p.106; Lulat 2005, p.2009). In this respect, GNM only baptized literate grownups. (Mambo 1980, Reverend Michael Gafo Hiribae, Wenje 18/10/2017; Reverend Francis Tumaini, Ngao 23/11/2017).By 1939, the GNM had baptized around 2500 people (Pakia \& Buya (1992). This practice of the GNM baptizing grown -ups with proven ability to read and write contributed to rapid growth of literacy among the Pokomo in the period the missionaries worked in the area.

Another unique feature of the GNM was that it believed that converts into Christianity needed to be separated from non-believers to protect them from being influenced back into heathen practices. This was known as congregational doctrine. The GNM missionaries initially lived with the pioneer converts in the missionary house on Ngao Hill. The pioneer converts who lived with the Germans became very instrumental in helping the missionaries to preach, teach and translate the Bible, hymns/songs and other literature into Kipokomo. One of them was Gudina Kanana believed to be the first literate person in Tana River. The house served both as a church as well as a classroom. Later on, the pioneer converts were built houses in or around the church compound. The researcher visited the house of Gudina Kanana, one of the pioneer converts which is now occupied by his grandson Mr. Enos Garisse Israel son of Teacher Israel Gudina. Mr. Enos Israel told the researcher, "My grandfather was built a house by the Germans next to the church (African Inland Church -AIC Ngao) as you can see, for being one of the earliest converts. Behind us is the family of Chadhoro Tutu the father of Amos Chadhoro, former Jeans school teacher and school inspector. The families of Pioneer converts are settled around the church." (Mr. Enos Garisse Israel, Ngao town 23/11/2017).

Jesus Christ commanded his followers to teach the new converts to be keen disciples who could also spread the Gospel further (Bible: NKJV Mathew 28:19-20). The missionaries believed that the best teaching could only happen when the students were in close proximity hence the congregational approach. The 1934 Tana River DC, Mr. A.C.M Mullins in his Annual Report captured this aspect and appeared to be uncomfortable with it. He writes:

The mission (GNM), in an endeavor to keep in close touch with its followers, works on the congregation system. Congregation is taken, however far too much in its narrower sense, and it 
is insisted that a member must live amongst the congregation (KNA/DC/TRD I/2 Tana River District Annual Report, 1934).

In 1935, the new DC, Mr. E.H Windley equally discussed this policy in his Report and also complained that it was conflicting with government policy. He writes:

The Mission (GNM) controls their adherents by a system of congregations at various centres of influence. The congregations tend to usurp the temporal authority of the tribunal elders and they need suppressing in this respect...(KNA/DC/ TRD 1/2 Tana River District Annual Report 1935)

The researcher noted that as much as the British authorities complained of the congregation system, the locals were for it and it is actually one of the reasons the Pokomo embraced the German missionaries more than the British missionaries like those of the Methodist Missionary Society (MMS). This was confirmed by Yekonia Deye Wayu, a 90 year old resident from Hola Mission area at Hola town who told the researcher that:

The German missionaries intermingled with us so freely like they were part of the Pokomo community. We would cook together rice and bananas and eat together. They grew very healthy from the Pokomo food. We loved them very much unlike other white people (Yekonia Deye Wayu (90), Hola town 17/10/2017).

This idea of separating converts from the general population appears to have been behind the establishment of boarding schools among the missionary organizations. Sifuna and Karugu (1988, p.5) have the following to say on the genesis of boarding schools:

The native student had to be kept away from retrogressive influences. Christian Africans had to be civilised; a process which could only be accomplished by taking them out of their pagan environment for a sufficient length of time. The [possibility] of pagan influence of students led to the necessity of boarding them.

Bogonko (1992, p.19) agrees with these sentiments when he says that with the establishment of mission stations came mission schools to teach the boarders. Welbourn $(1965$, p.84) agrees that only in separated communities did there seem to be the possibility of teaching the Christian life in its fullness. The GNM also established boarding schools and according to the 1932 Tana River District Annual Report, the DC, Mr J.H.B Murphy indicated that the GNM had 8 night (boarding) schools.

\section{(ii) The GNM as a Faith Mission}

Faith Mission is a term used most frequently among evangelical Christians to refer to a missionary organization with an approach to evangelism that encourages its missionaries to trust in God to provide the necessary resources. These missionaries are said to live by faith. Most faith missionaries are not financially supported by denominations (Tucker, 1983, p.335). The Faith Mission is an interdenominational agency which works closely with all Christian churches that share a similar concern for passionate evangelism (Nthamburi 1982). Anthony Norris Groves is referred to as the father of Faith Missions (Dann 2004). Faith missions had three main characteristics, namely: They were inter-denominational, evangelical in nature and 
missionaries funded their own activities. Tana River D.C. Mr. C.A Cornell in his 1930 Annual Report had the following to say of GNM missions:

The Neukirchener Mission at Ngao remains the only mission in the district. It is a purely evangelical trusting to a creed of faith, and for material support to voluntary donations from Germany and consequently appears somewhat poorly endowed (KNA DC/TRD 1/2 p.9)

The church elders, village elders and retired educationists interviewed, all indicated that the German missionaries identified with their home town of Neukirchen and not with any big mainstream home church like the Church Missionary Society - CMS (Anglican Church) and the Holy Ghost Fathers - HGF (Roman Catholic Church). They explained that they had been drawn from different denominations but brought together for a common good to evangelize to those still lost in sin. As a result they did not have the benefit of enjoying funding from any mother church like their contemporaries. The 1932 Education Report indicate that GNM work at Java and Neukirchen was state funded but the researcher found no evidence in the field of the German government ever funding or extending any aid to GNM missionaries in Tana River. This can explain the total and unreserved sacrifice exhibited by the GNM evangelists. Before being sent overseas, members of GNM underwent thorough training to prepare them for mission work and teaching (Gissel \&Gissel 1991). Another Faith Mission in Kenya was the Africa Inland Mission (AIM) which explains why the GNM entrusted their churches to the African Inland Church following their deportation (Nthamburi 1982).

\section{(iii) Reformed Theology Perspective}

The German Neukirchen Mission (GNM) adopted the doctrine of Reformed Theology whose proponent was The German Protestant Movement founder Martin Luther (1483-1546). The Theology emphasizes on in depth, keen and careful study and interpretation of scriptures, holy living, and helping the poor, needy and vulnerable in society. The underlying principle in this doctrine is a keen emphasis on ability of converts or faithfuls to be able to read and write so as to effectively understand and share the teachings of the Bible. In 1894, GNM preacher Reverend Ferdinand Wurtz baptized 8 pioneer converts after completing baptismal lessons. The 8 pioneer converts were Abdullah, Gudina Kanana, Kirage, Kiripa, Lulutya Kapanya, Subo Bonaya, Zamani and Chadhoro Tutu. In 1904 they had baptized 150; by 1911 the number had reached 442 (Mambo, 1980, Gissel \& Gissel, 1991, Pakia \& Buya, 1992). By 1940, the number was estimated at 2,500 (Pastor Gideon Malibe Galana, Wenje 18/10/2017). The researcher established in the field through FDGs that the name of the first convert mentioned above was not Abdullah but Abadula. Abdullah is a Swahili-Muslim name while Abadula is a Pokomo name. Several authors confused these names because of closeness in pronounciation.

One of the outcomes of Martin Luther's Protestant movement was the establishment of a church denomination named after him - The Lutheran Church. A denomination is a typical church started under the wider Christian faith and pursues a certain doctrine according to its typicality. A doctrine is a belief that is emphasized by a denomination that may differentiate it from other denominations in the Christian faith though they all agree on key fundamental principles or beliefs like on the founder Jesus Christ. The place in Hola where GNM opened a mission station is known as Hola Mission to this day. The researcher visited many Lutheran 
churches and interviewed a number of church elders and adherents notably Faris Jillo Dhadho (75), Lazaro Deye (80), Yekonia Deye Wayu (90), John Change Abagerera (70), Martin Galgalo Gharawa (92) and John Jarah Marigo (50) [Interviewed on 17-10-2017 in Hola town].

Various DCs in Tana River concurred that GNM missionaries and converts exhibited exemplary behaviour thus appearing to affirm what Reformed Theology stands for. Mr. W.R. McGeagh, Tana River DC in 1933 had this to say: "The native converts are found to be law abiding. Their taxes have been very promptly paid and their general behavior satisfactory" (KNA/DC/TRD 1/2 p.8). His successor the following year Mr. A.C.M. Mullins reported: "The adherents ... pay their taxes well, and are good workers when given the opportunity" (KNA/DC/TRD p. 14). In 1935, Mr. E. H. Windley, Tana River DC echoed the same words when he described the mission followers as well disciplined and law abiding. For the administrators to give such sentiments for GNM converts; it can only point out to the fact that they had compared them with others for instance those practicing traditional religion or converts of other missionary organizations and seen a big difference. The government officials were British not German meaning that their observations could be taken to be fairly objective. Such attributes as law abiding, hard working and well behaved were what Reformed Theology propagated for. The Church elders and adherents interviewed at Hola Mission affirmed that these practices among church members have remained to date.

\section{(iv) Social Darwinism Perspective}

The ideas of Charles Darwin on evolution influenced the development of Social Darwinism as an ideology which argued that different races were at different levels of evolution. Social Darwinists placed Africans at a lower level of development as compared to Europeans thereby justifying the latter's exploitation of the former, including the need to introduce their superior civilization upon them (Darwin 1971, Boahen 1990). Whereas this was the thinking in Europe in the $19^{\text {th }}$ and $20^{\text {th }}$ Centuries and determined how the Whites treated Blacks especially in colonial lands, there was no evidence found in the field about Germans looking down on Africans in Kenya/ Tana River on the basis of their colour. If GNM missionaries felt their civilization and religion was superior, then they kept it to themselves. According to 90-year-old Yekoma Deye Wayu: "It is the British who looked down upon us and oppressed us but not the Germans. We would invite the Germans in our ceremonies, eat rice, cassava and fish together before they taught us and preached to us. They were very good people". (Hola, 17/10/2017).

Available documented evidence on Europeans perception of Tana River people is from the provincial administration which was made up of British officials. In the 1917/1918 Tana River District Annual Report, the DC, Mr. J. W. K. Peaze described the Pokomo as 'a most unprogressive tribe...their villages are dirtier and more tumble down than ever' (KNA/DC/TRD I/1 1917-1926). The same words are echoed in the 1920/21 Report which reads in part, "The Wa-Pokomo who form the bulk of the population are cultivators... They are unprogressive and show little change since 1914 when the present Ag. DC was stationed here... the level of their intelligence being by no means low."

But it is Major A.W. Sutcliffe, the Assistant DC who in 1925 Report did not mince words in negatively portraying the Pokomo. He unashamedly asserted: 
The Pokomo are typical swamp dwellers... inappropriately thin legged, they suggest the pugilist build, their feet are large, flat and 'splay' through generations of walking in mud and water... timid, shy, simple minded, ignorant, unambitious, unenterprising, lethargic, disease racked, alternately gorged without food or existing on bush fruits, highly inbred, living in an eternally fever impregnated state, drinking micaceous water drawn from the river, which is the water borne sanitary system of the whole tribe; they are undoubtedly a declining race which nothing short of absolute revolution of conditions can save. The foundations of this have been laid down this year (KNA/DC/TRD 1/1 1917-1926 p.82).

The Assistant DC in the last statement may have been referring to Colonial Government efforts to improve education standards in the area coupled with evangelization efforts by the Methodist mission which was mandated by the British Colonial Government to inherit the Neukirchen Missions. Though some of the observations he raises above could be true, one cannot fail to see the obvious bias, exaggeration, negative attitude and superiority complex. Sifuna and Karugu (1988, p. 3) while looking at education during the colonial period in German occupied Tanganyika agree with this statement by saying that German colonial policy like that of other colonial powers was to subjugate the cultures of the colonial people using Western Education. However, government established schools and missions established schools slightly differed in their curriculum in that the former aimed at producing workers to serve in government while the later majored on religious instruction. The German missionaries in Tana River appear to have followed the same policy of concentrating more on religious instruction and evangelism in order to avoid a conflict of interest with the governing power which was Britain. The GNM however appear to have been cautious not to politicize their agenda in a country governed by a different European power or could as well have resolved to stick to spreading the gospel as it is in which all people/ races are depicted as equal before God. (The Bible: KJV Romans 2:11).

Such statements with racial undertones may not all the same be treated as the official position of the British administration though were most popular at the time and largely influenced how the average European perceived the African. Mr. W.H. Taylor, the Coast Inspector of Schools, reported in his 1928 and 1929 Reports that among the Pokomo, "It is noteworthy and altogether encouraging to find a tribe so keen on schools. This desire it will be observed, is not confined purely to the male portion of the population. The girls and married women show a great keenness in learning to read and write as the boys and young men" (KNA/ED/1/4/3 Sectorisation Report of Tana River District $8^{\text {th }}$ July 1929 p.4). This clearly portrays the Pokomo not as lazy as the DC put it meaning it could have been his personal perception. On spiritual matters, Rev. J. Jackson of the Methodist church described the Pokomo in 1927 as "religious and reverent... with a genius for worship, a capacity for adoration, which does not come readily to the average Englishman" (Jackson, 1927; Quoted in Nthamburi, 1982 p.48).

Rev. J.B. Griffiths of the MMS had earlier in 1918 while on a visit to Tana River encouraged MMS to continue with GNM`s work after the latter were banned following the outbreak of WW II. He said, "The Tana is certainly unhealthy, but I plead with our people not to run away from the most responsible tribes in East Africa (United Methodist Church Annual Report 1918, p.50). This then shows that there were mixed perceptions as to how Europeans viewed Africans 
even though Social Darwinism heavily influenced their racial standpoint. As concerns the GNM in Tana River, no evidence gathered suggested that they considered and treated Africans as a lesser race.

\section{(v) Socio-Political and Economic Perspective}

The sharing out of the countries on the African continent by the Europeans at the Berlin conference of $1884 / 85$ was pegged on socio-political and economic ties that may have existed between the interested European power and the region in question. In the 1880s, Clemens and Gustav Denhart had staked a claim on Wituland on the Kenyan Coast which later attracted the GNM (Mambo 1980). It is likely they were influenced by the activities of Carl Peters of the German East Africa Company (GEAC) who had traversed the area hurriedly and signed treaties with some local chiefs to the dismay of the British Government which believed the region belonged to her. As Nthamburi (1982, p.57) postulates, the granting of charters to business companies by their home governments had a direct bearing on the expansion of missionary activities. The company owners encouraged missionaries from their home to start working among the people on whom they had some influence.

A hardwritten diary found at the Kenya National Archives seemingly authored by a British explorer and Imperial British East Africa Company (IBEAC) official but lacking his name and actual dates as some papers are missing; gives an account of Carl Peters' travels in the Tana. Its authenticity is ascertained by the fact that it agrees with what is documented in Christopher Wilson's book, Before the Dawn in Kenya (1952). It says in part:

Sethe (The Galla chief of the district: see April 1) Was soon after I left murdered by the notorious Dr. Carl Peters, who followed me up the Tana and who went on to Uganda trying to get hold of all the country for Germany: but everywhere he was late... He got hold of the treaties I had made with the chiefs and the company's (IBEAC) flag I had given them and destroyed them. He then wrote to a friend in Germany, telling him what he had done. The friend immediately published his letters in a Germany newspaper, thereby proving most satisfactorily that I had been up before him and had established the British claim to the whole of the left bank of the Tana (My Diary Account of My Journey up the Tana River through Ukambani and along The Sabaki River; unauthored, n.d).

The differences between Britain and Germany on their claims on East Africa were resolved after the Berlin Conference in 1890 whereby Tana/ Wituland remained part of British East Africa while Germany got compensated with Heligoland Island in Europe. By the time this treaty/ agreement was being signed, the GNM missionaries had already started their mission work in the Tana.

Admittedly, various missionary organizations invited their home governments to the countries they evangelized to invest and exert colonial control to the advantage of missionary work. Missionary David Livingstone of United Missions to Central Africa (UMCA) subscribed to this school of thought (Gration, 1973). As has been seen, the socio-economic and political factors remotely influenced the coming of the GNM to Tana River. However, the respondents could not relate the coming of the GNM with these factors. 


\section{Conclusion}

The findings of this study have a bearing on education in Tana River County in particular and Kenya in general especially against a backdrop of education being all inclusive and as an agent of community transformation. It is evident that though Arid and Semi-Arid Lands (ASALs) were largely shunned by many missionary organizations, the GNM established itself among the Pokomo in Tana River County and in the first half of the $20^{\text {th }}$ century could be said to have competed favourably with other regions in Kenya where there were missionaries in terms of acquisition of Western education. The GNM deserves its rightful place in the history of education in Kenya because evidently, its contribution in laying the foundation for Western education in Tana River County cannot be over emphasized. In addition, the number of institutions opened in the study area by GNM clearly shows that education can be advanced and developed in any region, challenges notwithstanding.

\subsection{The Great Commission Perspective and Education}

The "Great Commission" perspective underscores the call and need to provide education equally to all people. The so-called marginalized areas have been left out in development matters including education provision. Tana River County is one of the 14 marginalized Counties in Kenya (KUCCPS, 2014). The Kenya Universities and Colleges Central Placement Service (KUCCPS) through Affirmative Action lowers 5 points for students in these areas when making college and university admissions. It also lowers 2 points for girls to enable them access higher education equitably with the boys.

As earlier explained, Jesus Christ urged his followers to take the Gospel to all the corners of the World. Missionaries were obeying this command and literacy skills were a prerequisite for preaching the Gospel. Jesus Christ himself was referred to as 'Rabbi' which in Hebrew means Teacher (The Bible NKJV Matthew 19: 16; 23:8). He addressed the needs of people of all walks of life - men, women, the poor, the rich, the sick (e.g. disabled) and even little children (Matthew 19:13-15). In like manner, education should be provided to people of all walks of life regardless of their shortcomings.

\subsection{The Faith Mission Perspective and Education}

The "Faith Mission" perspective calls for teachers and other educationists to be willing to work in far from home and so-called hardship areas as they practice the noble profession. Urban areas and other well to do regions have attracted more teachers to the extent of being over-staffed at the expense of ASALs. The ongoing Teachers Service Commission program of delocalization of teachers and principals (2018) is a step in the right direction though should address security concerns in certain regions, pay allowances accordingly and look at family concerns especially of those about to retire (Owino,2019 \& Okendo, 2019). Nevertheless, even if the teachers' terms of service are improved, there is still need for sacrifice and a patriotic attitude resulting from the desire to impart knowledge and fight ignorance as well as serve one's country. The GNM missionaries were volunteers from different churches in Germany without stable financial support from back home. They depended on themselves and well-wishers to carry out their activities in Tana River County. Teaching like preaching goes 
beyond the call of duty. This has been exhibited by, for instance, the Kenyan teacher of Mathematics and Physics at Keriko Mixed Day Secondary School in Nakuru County, Mr. Peter Tabichi, who won the coveted World Teacher of the Year Award 2019 in Dubai, and was honoured for among other things, going beyond duty and using his salary to pay fees for needy pupils (Matara, 2019). Mr Tabichi's achievement is "Faith Mission" perspective at its best when applied in the education sector.

\subsection{The Reformed Theology Perspective and Education}

Martin Luther's Reformation Movement of the $16^{\text {th }}$ century, which influenced GNM's ideology, held in high regard the aspect of good education. The "Reformed Theology" perspective therefore emphasizes the undisputed benefits of education to society. A literate citizenry will contribute to the development of the county in all spheres of life. Such spheres include socio-political and economic aspects of the nation. Good education does not only benefit the country but also the people at individual level through acquisition of skills for living and earning a livelihood. Nevertheless, those well positioned socially, politically and economically should endeavor to see others uplifted and not exploit them.

\subsection{Social Darwinism Perspective and Education}

The "Social Darwinism" standpoint appeals to all not to deny educational services and indeed all vital services to any people based on colour, ethnicity, gender, religion, physical appearance or any other trait. Nothing intrinsic or inborn makes Tana River County and by extension other such Counties not to perform well in national examinations.

\section{Recommendations}

The National Government should do more than has been done to sustain and continue the good work started by the GNM especially in the education sector. The following recommendations have been suggested:

\subsection{Improve the Infrastructure}

Most of the primary schools started in the area lack adequate infrastructure ranging from classrooms to furniture. Transport has remained a big challenge in the county to date. The only tarmac road in the County is from Malindi to Garsen and Nairobi to the neighbouring Garissa County. From Garissa to Hola, the County headquarters, there is no tarmac though under construction. This is long overdue. Poor road network affects education negatively since fewer institutions would be established and not many teachers and education officials would be willing to work in such areas. In addition, delivery of learning resources and administration of national examinations not to mention inspection of the teaching - learning process equally suffers a great deal due to impassable roads.

\subsection{Invest More in TVET Institutions}

The County does not perform so well in national examinations obviously because of the many challenges highlighted but is full of talent like in other counties in the country. The National Government in collaboration with the County Government needs to invest more in Technical 
and Vocational Education and Training (TVET) institutions. Such institutions would absorb a big chunk of high school leavers who miss out in university admissions as well as provide technical manpower needed in the economy in line with the country's Vision 2030 and The Big 4 Agenda. The County has four Youth Polytechnics namely Tarasaa, Hola, Maziwa and Tumaini (County Government of Tana River, 2017). These could be expanded and two or three more opened in other areas. The Music talent evident in the County can be nurtured in such institutions.

\subsection{Opening a Secondary School Wing in every Primary School}

Each primary school in the County should open a secondary school wing owing to the transport problem in the area. This is also in line with Government policy since 2017 of $100 \%$ transition from primary to secondary school (Bonyo, 2020). The National Government should also post adequate teachers to the County, compensate them appropriately and assure them of their security. Indeed, the national government through the ministry of internal security has a duty to ensure the County is safe so that both locals and non- locals in Tana River can feel save to invest, live and work in the area. This being the case, education would gain since more teachers and students would be willing to teach and study there. Cases of internally displaced people - most of them being children of school going age - would be unheard of.

\subsection{Teachers' Rights vis-à-vis Learners' Plight}

Teachers ought to see their calling as being beyond duty or as means to earn a livelihood. By emulating the GNM missionaries cum educationists, they should be ready to work in any part of the country where they are posted. They should perceive it as service to God and derive satisfaction from the realization that they have helped young ones placed under their care to acquire education. The Teachers Unions of the Kenya National Union of Teachers (KNUT) and the Kenya Union of Post Primary Education Teachers (KUPPET) should not only agitate for better terms of service but should also sensitize teachers about their critical role in making education available to all children who turn out in schools in pursuit of knowledge.

\subsection{Establish an Institution of Higher Learning}

The National Government can consider starting a university there or University College to serve both Tana River and the neighbouring Lamu County which lack such a facility. This is in line with the dream of GNM's educationist Herman Muller who saw the region as capable of competing equally with the rest of Kenya in matters of education. 39 out of the 47 counties in Kenya have an institution of higher learning (CUE, 2019) and Tana River should not be an exception. Such an institution could motivate the learners in the region to aspire for higher education and also remove the perception of being marginalized in educational matters.

\section{References}

Bantock, G. H. (1980). Studies in the History of Educational Theory V.1. London: George Allan \& Unwin.

Beecher, L. J. (1949). African Education in Kenya. Report of a committee appointed to inquire 
into the scope, content, and methods of African education, its administration and finance, and to make recommendations. [Chairman: L.J. Beacher.]. Nairobi: Government Printer.

Boahen, A.Adu. (1990). UNESCO General History of Africa vol. VII: Africa Under Colonial Domination 1880-1935. Nairobi: Heinemann.

Bogonko,S. N. (1992). A History of modern Education in Kenya (1895-1991). Nairobi: Evans Brother.

Bonyo, E. (2020, January 24). Data will be crucial in achieving 100 per cent education transition. The Standard. Retrieved from https://www.standardmedia.co.ke/opinion/article/2001357708/data-will-be-crucial-in-achievi ng-100-per-cent-education-transition

Castleman, R. F. (2007). The Last Word: The Great Commission: Ecclesiology. Themelios: An International Journal for Pastors and Students of Theological and Religious Studies, 32(3), 1-70.

Commission for University Education (2019). Approved academic programmes offered in chartered universities in Kenya in accordance with the universities act Nairobi: CUE. Retrieved from http://www.cue.or.ke/index.php/approved-academic-programmes

County Government of Tana River. (2017). About us. Retrieved from http://www.tanariver.go.ke/about-us-2/: Accessed 29/8/2020.

Dann, R. B. (2004). Father of Faith Missions: The Life and Times of Anthony Norris Groves (1795-1853). New York: Authentic Media.

Darwin, C. R. (1971). The Origin of Species. New York: Ep Dulton \& Co Inc.

Gissel,F. \& Gissel, H (1991). Einhundert Jahre Neukirchen Mission am Tana 1887-1987 (A Hundred Years of Mission in Tana: The Neukirchen Mission in 1887-1987). Saarbrucken: Homo ET Religio.

Gration, J. A. (1973). The Relationship of the African Inland Mission and its National Church in Kenya 1895 and 1971 (Ph.D Dissertation, New York University).

Government of Kenya. (2016). State Department of Planning and Devolution, Ministry of Devolution and Planning. (2016). Sustainable development goals. Retrieveed from www.sustainabledevelopment.unorf/sdgs.

Jackson, J. (1982). The Wapokomo in the missionary echo of the Methodist Church 1927, In Z. J. Nthamburi, A history of the Methodist church in Kenya. Nairobi: Uzima Press Ltd.

Kenya National Archives. (1926). KNA/DC/TRD 1/1: Tana River District Annual Report 1917-1926. Nairobi: KNA.

Kenya National Archives. (1929). KNA/ED/1/4/3: Colony and Protectorate of Kenya Office of P.C Coast, Mombasa PC/Coast/2/10/11. Nairobi: KNA.

Kenya National Archives. (1930). KNA DC/TRD 1/2: Tana River District Annual Report. 
Nairobi: KNA.

Kenya National Archives (1932). KNA/DC/ TRD 1/2: Tana River District Annual Report. Nairobi: KNA.

Kenya National Archives. (1933). KNA/DC/TRD 1/2: Tana River District Annual Report. Nairobi: KNA.

Kenya National Archives. (1934). KNA/DC/ TRD 1/2 Tana River District Annual Report. Nairobi: KNA.

Kenya National Archives. (1935). KNA/DC/ TRD 1/2 Tana River District Annual Report. Nairobi: KNA.

Kenya National Archives. (1929). KNA/ED/1/4/3 Sectorisation Report of Tana River District. Nairobi: KNA.

Kenya Universities and Colleges Central Placement Service. (2019). List of universities and colleges in Kenya. Retrieved from https://www.advance-africa.com/Universities-in-Kenya.html.

$\begin{array}{llll}\text { Kenya } & \text { Vision } & \text { Retrieved } & \text { from }\end{array}$ http://vision2030.go.ke/inc/uploads/2018/05/Vision-2030-Popular-Version.pdf.

Lulat, Y. G. M (2005). A History of Higher Education from Antiquity to the Present: A critical Synthesis. Wesport: Connpraeger.

Mambo, R. M. (1980). Challenges of Western Education in the Coast Province of Kenya, 1890-1963 (Ph.D Dissertation, Columbia University).

Matara, E. (2019, March 24). Kenya's Peter Tabichi Crowned World's Best Teacher. Daily Nation. Retrieved from https://www.nation.co.ke/news/Kenyan-science-teacher-wins-Sh100m-prize/1056-5040250-p yde0q/index.html

Nthamburi, Z. J. (1982). A History of the Methodist Church in Kenya. Nairobi: Uzima Press Ltd.

Okendo, B. (2019, Dec. 31). 2000 School Heads Moved in New Changes. The Standard. Retrieved from https://www.standardmedia.co.ke/article/2001354854/2-000-school-headsmoved-in-new-changes

Owino, S. (2019, April 16). TSC Says only New Teachers, Administrators will be Transferred. Daily Nation. Retrieved from https://www.nation.co.ke/news/education/TSC-spares-older-sick-teachers-in-transfers/2643604-5074480-k1 okhq/index.html.

Pakia, J.M.P \& Buya, L.M. (1992). Kufika kwa Ukristo Tana River District, Kenya: The Arrival of Christianity in Tana River District, Kenya (Unpublished).

Reformed

Theology.

Retrieved

from

http://www.gotquestions.net/printer/reformed-theology-PF.html?ga= 


\section{Macrothink}

International Journal of Learning and Development

Sheffield, J. R. (1971). Education in the Republic of Kenya. Washington, D.C.: Office of Education.

SDGs (2015). Retrived from: www.sustainabledevelopment.un.orf/sdgs

Sifuna, D. N., \& Karugu, A. M. (1988). Contemporary issues in Education in East Africa: Series on Provision of leadership in Teacher Education. Nairobi: Kenyatta University.

Sifuna, D. N., \& Otiende, J. E. (1994). An Introductory History of Education. Nairobi: University of Nairobi Press.

Smith, J. S. (1973). The History of the Alliance High School. Nairobi: Heinemann Educational Books.

The Bible. New King James Version: Nashville, TN: Thomas Nelson Publishers.

Tucker, (1983). Faith Mission. Retrieved from https://en.wikipedia.org/wiki/Faith-Mission.

Uhuru Kenyatta. (2017). The Big 4 Agenda. Retrieved from https://www.delivery.go.ke/flagship

United Nations, Department of Economic and Social Affairs Disability. (2018). Sustainable Development Goals (SDGs) and Disability. Retrieved from https://www.un.org/development/desa/disabilities/about-us/sustainable-development-goals-sd gs-and-disability.html.

United Methodist Church. (1973). Annual report. Retrieved from http://holgatedigitallibrary.bennett.edu/finding-aids/documents/united-A102/series4

Welbourn, F. B. (1965). East African Christian. London: Oxford University Press.

Wilson, C. (1952). Before the Dawn in Kenya. Nairobi: English Press Ltd.

Wakiaga, P. (2018). Why TVET is a Game Changer in Kenya. Retrieved from http://kam.co.ke/tvet-game-changer-kenya/

\section{Copyright Disclaimer}

Copyright for this article is retained by the author(s), with first publication rights granted to the journal.

This is an open-access article distributed under the terms and conditions of the Creative Commons Attribution license (http://creativecommons.org/licenses/by/4.0/). 